\title{
National general truck drivers' strike and food security in a Brazilian metropolis
}

\author{
Mariana Souza Lopes ${ }^{1}$, Melissa Luciana de Araújo ${ }^{2}$ and Aline Cristine Souza Lopes ${ }^{3, *}$ \\ 'Universidade Federal de Minas Gerais, Research Group on Nutrition Interventions, Belo Horizonte, MG, Brazil: \\ ${ }^{2}$ Universidade Federal de Minas Gerais, Research Group on Urban Agriculture, Belo Horizonte, MG, Brazil: ${ }^{3}$ Nutrition \\ Department, Universidade Federal de Minas Gerais, Research Group on Nutrition Interventions, Alfredo Balena \\ Avenue 190, Room 316, Santa Efigênia, Belo Horizonte, MG 30130-100, Brazil
}

Submitted 2 July 2018: Final revision received 29 March 2019: Accepted 24 April 2019: First published online 9 August 2019

\begin{abstract}
Objective: We analysed the impact of the national general truck drivers' strike on the availability, variety and price of foods sold by a food supply centre.

Design: Descriptive study using secondary data to examine the percentage change in the mean price of fruits, vegetables and eggs before, during and after the strike. The strike in Brazil lasted 10 d from 21 to 30 May 2018. The drivers were on strike in order to make diesel oil tax-free and to obtain better working conditions.

Setting: The food supply centre, named CEASA-Minas Grande BH, was located in the metropolitan area of a Brazilian city.

Participants: We examined twenty types of foods.

Results: After $10 \mathrm{~d}$, there was a $\sim 30 \%$ reduction in the availability of all types of foods and prices increased. Foods with the highest price increases included cabbage $(233.3 \%)$, potatoes (220.0\%), papaya (160.0\%) and oranges (78.6\%). At the end of the strike, we observed reductions in the price of eggs, fruits, vegetables, roots and tubers; however, some foods remained more expensive than before the strike, including chayote (203.2\% higher), cucumber (66.7\% higher) and potatoes (60.0\% higher).

Conclusions: The general truck drivers' strike was correlated with a reduction in the availability of food and, consequently, increases in price and possibly restrictions on access. The strike demonstrated the dependence of metropolises on road transportation and the conventional market. We speculate that initiatives aiming to shorten the food supply chain and promote food sovereignty and resilience of the supply circuits could be important.
\end{abstract}

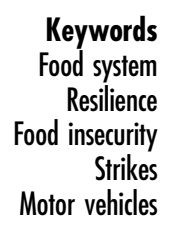

Food security exists when people have, at all times, a guaranteed and adequate food supply. Food security involves access to sufficient, safe and nutritious food that meets individual dietary requirements and food preferences for a healthy life without restricting access to other fundamental needs ${ }^{(1)}$ and sovereignty ${ }^{(2)}$. Therefore, the risk of food insecurity is influenced by the availability, price, access and quality of the food supply to the consumer, especially in a crisis situation ${ }^{(3)}$. Studies that have explored the global food crisis and market instability indicate that there is an independent association between crisis situations and food security ${ }^{(4,5)}$. For example, a recent Brazilian study showed that there was a marked increase in the prevalence of food insecurity during the Brazilian economic crisis $^{(4)}$.
In Brazil, the Centrais de Abastecimento de Minas Gerais S.A. (CEASA-MINAS) distributes produce. The aims of the CEASA-MINAS are to: (i) improve the process of marketing and distribution of products; and (ii) connect producers and consumers in urban centres. The CEASA-MINAS is supported by mixed-capital (public and private) resources and operates under governmental supervision. Consequently, the CEASA-MINAS plays an important role in guaranteeing food security and the human right to food ${ }^{(6)}$.

The state of Minas Gerais is the third-largest economy in Brazil and has one of the best transport networks in the country. The CEASA-MINAS has six units in this state and its headquarters is in the city of Contagem, in the metropolitan region of Belo Horizonte. The headquarters is the principal unit and is named CEASA-Minas Grande $\mathrm{BH}^{(7)}$. 
In 2018, the CEASA-Minas Grande BH traded about 2000 tonnes of food, which corresponded to $80 \%$ of the total market in the state ${ }^{(8)}$. Therefore, this business unit is the subject of the present study.

The supply of unprocessed or minimally processed foods* in the CEASA-MINAS is self-supplied by the state of Minas Gerais. In spite of this, food is transported via long routes in the state due to its large territory $\left(586528 \mathrm{~km}^{2}\right)$. The distribution network is more complex for fruit. The supply of fruit at the CEASA-Minas Grande BH has multiple origins and the fruits are carried by trucks over long distances. Some leafy vegetables are produced near the food supply centre ${ }^{(10)}$. In general, the food supply of the CEASA-Minas Grande BH covers a radius of $200 \mathrm{~km}$, but there are items that originate from distances of up to $2000 \mathrm{~km}$ away ${ }^{(11)}$. The 1081 municipality suppliers of the CEASA-Minas Grande BH move, on average, 25700 trucks per month via Brazilian roadways ${ }^{(8)}$.

Consequently, a national general truck drivers' strike may have important consequences for the economy and food supply chain of a country that is dependent on road networks. Such an event occurred on 21-30 May 2018. During this $10 \mathrm{~d}$ strike, Brazilians experienced an extreme event characterized by roadblocks and the unavailability of fuel, medicine, food, and the inputs for food production processes. The disruption of the supply of animal feed had a devastating impact: millions of chickens and pigs were slaughtered because producers had no food for them ${ }^{(12)}$. The drivers were on strike in order to make diesel oil tax-free and to obtain better working conditions ${ }^{(13)}$.

Despite the drivers' important claims, in a crisis situation, $200 \mathrm{~km}$ can be as long as $2000 \mathrm{~km}$ and the repercussions may result in negative impacts for food security. Given the importance of transport conditions for the food security of the Brazilian population, the present paper aimed to analyse the impact of the national general truck drivers' strike on the availability, variety and price of unprocessed foods sold by a food supply centre in a Brazilian metropolis.

\section{Methods}

The national general truck drivers' strike in Brazil lasted $10 \mathrm{~d}$ from 21 to 30 May 2018. To verify whether the market stabilized, we analysed data regarding different types of unprocessed foods over the following days: 18 May $(3 \mathrm{~d}$ before the strike; to identify the routine of the market),

"In this study, in particular, we use the term 'unprocessed food' to mean 'unprocessed or minimally processed food'. Unprocessed foods are edible parts of plants (fruits, vegetables, leaves or roots) or animals (eggs) after separation from nature. Minimally processed foods are natural foods that are altered by processes such as removal of inedible or unwanted parts, drying, crushing, grinding, fractioning, filtering, roasting, boiling, pasteurization, refrigeration, freezing, placing in containers, vacuum packaging or non-alcoholic fermentation. None of these processes adds substances, such as salt, sugar, oils or fats, to the original food ${ }^{(9)}$.
21 May (the start of the strike), 22-24 May (the 2nd to 4 th days of the strike), 30 May (the end of the strike) and 4-6 June (1 week after the end of the strike). The periods from 25 to 29 May 2018 and from 31 May to 3 June 2018 were not analysed because data were not available.

\section{Database}

Data were obtained from the institutional site for the food supply centre (http://www.ceasaminas.com.br/). The market information of the daily price bulletin was filtered by food group (eggs, fruits, vegetables, roots and tubers). We analysed only those data from the CEASA-Minas Grande BH.

\section{Variables}

Among the more than 200 items available in the database, we analysed the twenty unprocessed foods that are most frequently consumed by Brazilians: lettuce, kale, cabbage, pumpkin, carrot, chayote, cucumber, sweet potato, potato, cassava, grape, tomato, tangerine, watermelon, banana, orange, apple, papaya, mango ${ }^{(14)}$ and eggs. Therefore, we analysed: one type of egg, eight fruits, three leafy vegetables, four vegetables, and four roots and tubers.

We defined the varieties of items to be analysed according to the flowchart in Fig. 1. When an item included more than one type, such as oranges, only one type was analysed. The choice was made among those included in the database as of 30 May 2018, which were commonly available on the market (e.g. there are different types of oranges, but the most common type on the market is 'orange bahia'). When more than one type was commonly found on the market (e.g. 'banana prata' and 'banana caturra'), the type with the lowest price was used for the analysis. For foods that did not have more than one type but did consist of different sizes (e.g. watermelon), an item of average size was considered. To define the item that was commonly available on the market, we used the market information of the food filtered by year (2018) available on the website of the CEASA-MINAS (https://minas1. ceasa.mg.gov.br/detec/ofertas_prd_var/ofertas_prd_var. php $)^{(15)}$ and previous experience of the research group on the topic.

We investigated the mean price, in US dollars, of eggs, fruit, vegetables, roots and tubers. The mean price of a dozen eggs was estimated based on the price of thirty dozen (data available).

In addition, we investigated the variation in the mean price by separating products by the distance the food was transported (up to $250 \mathrm{~km} ; 251-500 \mathrm{~km}$; $501-$ $750 \mathrm{~km}$; and over $750 \mathrm{~km}$ ) to understand if there was a relationship between the change in price and distance. The mean route distance, in kilometres, for the unprocessed foods was analysed by an index developed by the CEASA-Minas Grande BH (Índice de Quilometrização). The index selected thirteen main products that were traded 


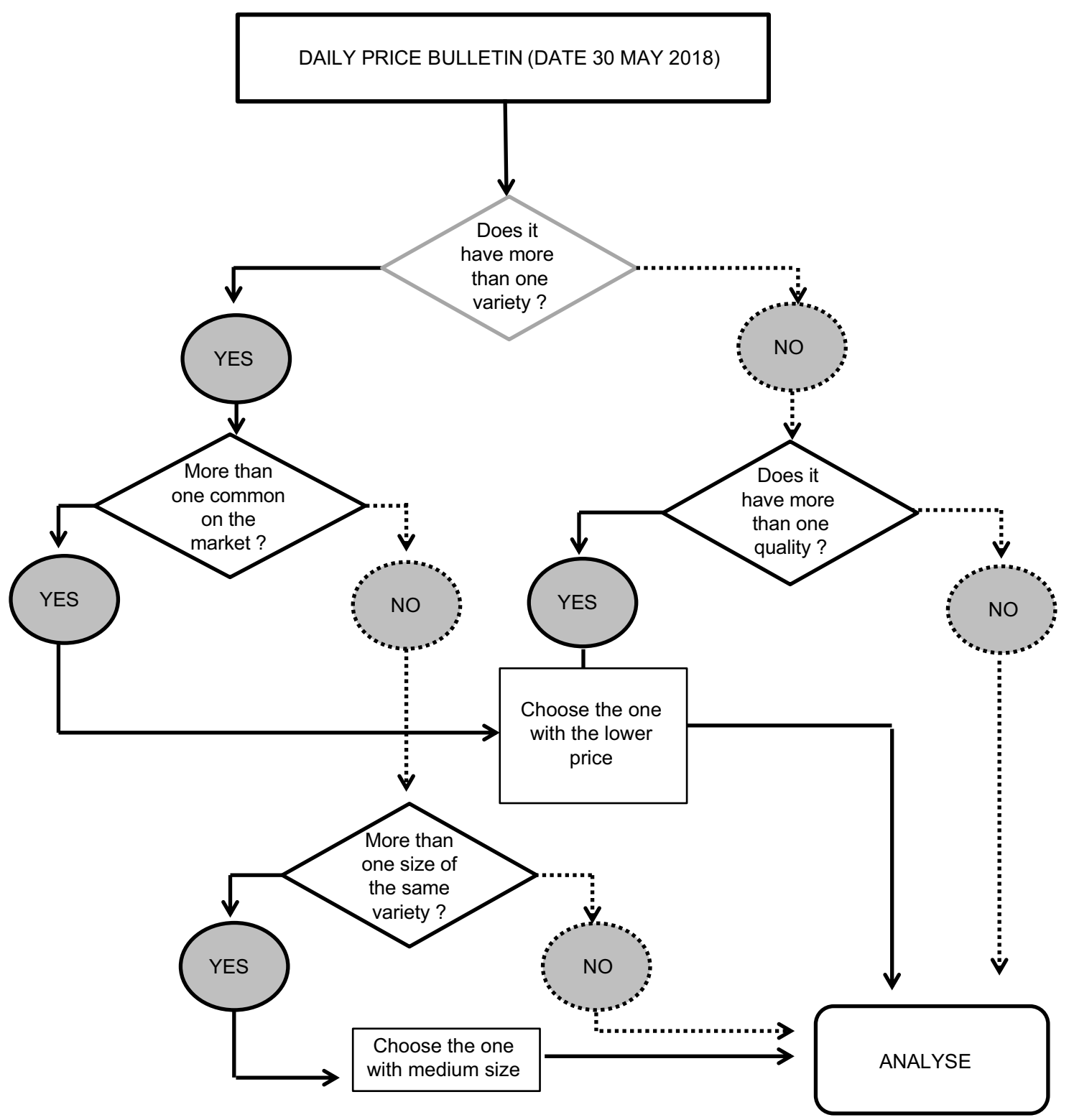

Fig. 1 Flowchart for choice of fruit and vegetable items, according to variety, before, during and after the national general truck drivers' strike affecting inland transport of loads in Brazil, 2018. To define the item that was commonly available on the market, we used the market information of the food filtered by year 2018 available on the website of the CEASA-MINAS (https://minas1.ceasa.mg.gov.br/ detec/ofertas_prd_var/ofertas_prd_var.php) $)^{(15)}$ and previous experience of the research group on the topic (CEASA-MINAS, Centrais de Abastecimento de Minas Gerais S.A.)

at the CEASA-Minas Grande BH. Data for mango, tangerine, grape, lettuce, kale, chayote, cucumber, sweet potato and cassava were not available.

To calculate the transport distance, in kilometres, for the unprocessed foods to the CEASA-Minas Grande BH, it was necessary to first identify which municipalities had greater or more significant transaction volumes for each of the analysed items; the 90th percentile was chosen as a 'cut-off point' to identify such municipalities. In other words, the municipalities for which the volume transported to the CEASA-Minas Grande BH was equal to or higher than the 90th percentile were selected and the mean distances (in kilometres) between these municipalities and the
CEASA-Minas Grande BH were calculated ${ }^{(16)}$. To calculate the distance, we followed the paths of the roadways.

\section{Analysis}

To analyse the reduction in the variety of foods available throughout the strike (including type and quality), we accounted for each of the twenty items and identified the number of different types and levels of quality available.

The percentage change in price before and after the strike was calculated as follows: (i) Variation between the mean price before (18 May) and at the end of the strike $(30$ May $)=\{[($ mean price of 30 May - mean price of 


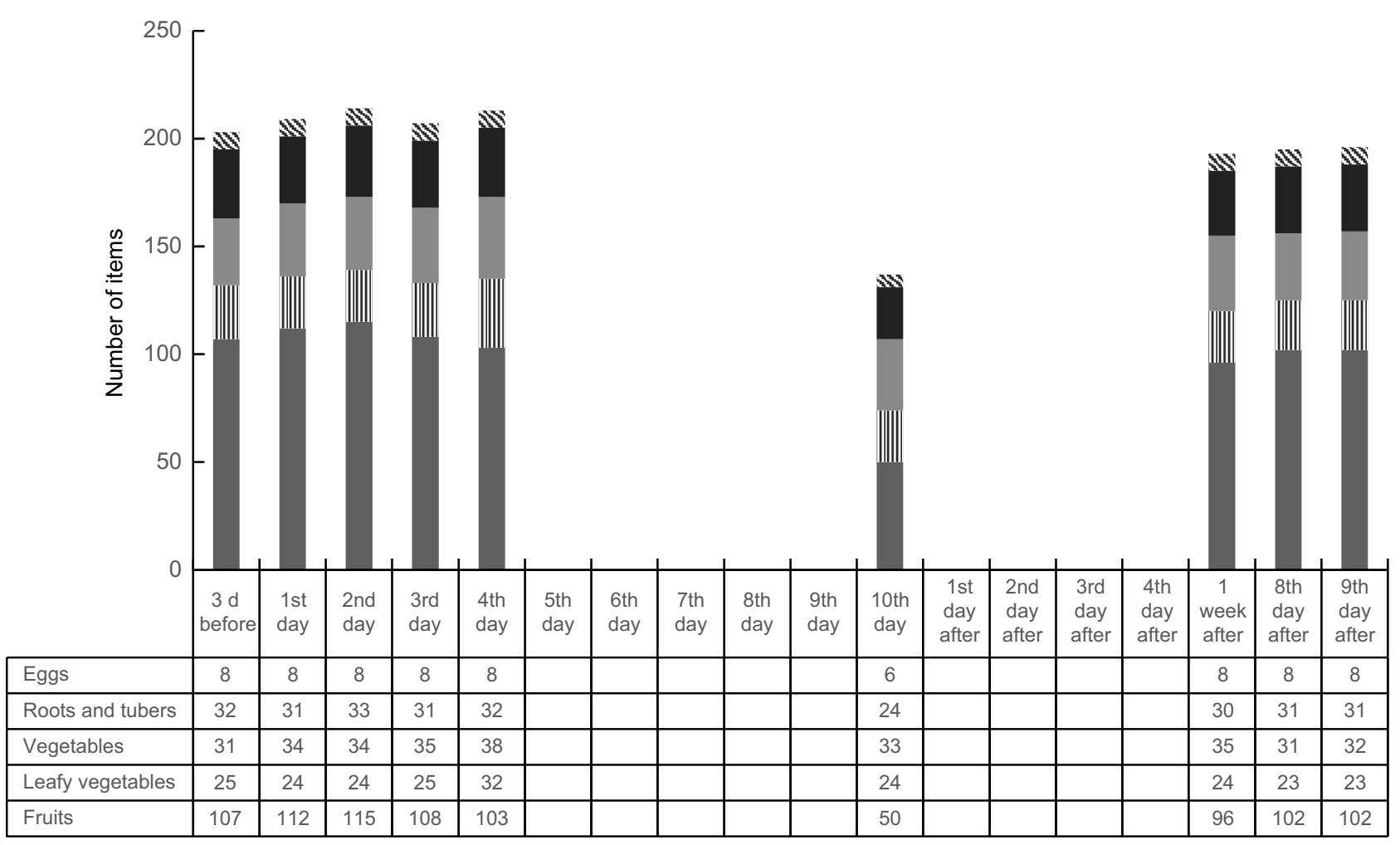

Fig. 2 The number of unprocessed food items and marketed types of unprocessed foods, according to food group ( $\square$, fruits; III, leafy vegetables; $\square$, vegetables; $\mathbf{n}$, roots and tubers; $\mathrm{s}$, eggs), before, during and after the national general truck drivers' strike in Brazil, 2018

18 May)/mean price of 18 May] $\times 100\}$; (ii) Variation between the mean price before (18 May) and 1 week after the end of the strike $(6$ June $)=\{[($ mean price of 6 June - mean price of 18 May)/mean price of 18 May] $\times 100\}$.

\section{Results}

Before the national general truck drivers' strike in Brazil (18 May), 203 types of unprocessed foods of different types and levels of quality were marketed at the CEASA-Minas Grande $\mathrm{BH}$. At the beginning of the strike, until the fourth day, some products continued to reach the CEASA-Minas Grande BH site and the number of items available was greater than 200; however, after $10 \mathrm{~d}$ of the strike (30 May), this number decreased to 137 . This was a $\sim 30 \%$ reduction in product availability. After the strike (6 June), more than 196 items became available for marketing. Fruits, roots and tubers suffered the most during this period (Fig. 2).

In comparison to the days before the strike, an important percentage change in food price was observed during the strike (18 May $v$. 30 May). We observed increased prices for a substantial number of fruits, which were greatest for papaya $(160.0 \%)$ and oranges $(78.6 \%)$. For leafy vegetables, small percentage changes were observed, except for cabbage $(233.3 \%)$. Eggs $(38.5 \%)$, other vegetables (chayote, $51.6 \%$; cucumber, $49.2 \%$ ), and roots and tubers (carrot, $40.0 \%$ ) also increased in price. Potatoes (220.0\%) and cabbage (233.3\%) suffered the highest price increases during the strike (see online supplementary material, Supplemental Table S1; Fig. 3).

In general, the availability of the investigated items decreased during and immediately after the strike, except for some vegetables. Prices for chayote (203.2\%), cucumbers $(66.7 \%)$ and potatoes $(60.0 \%)$ remained higher after the strike. When we analysed different time points (before, during and after the truckers' strike), oranges, papayas, pumpkins, cabbage and potatoes suffered the greatest price increases. There was a tendency for prices to stabilize after the strike, with the exception of chayote prices (Supplemental Table S1; Fig. 3).

Furthermore, when we analysed the change in food price according to the transport distance, we identified that two of the three unprocessed foods (potato and papaya) with the greatest percentage change in price (during the strike) travelled distances greater than $400 \mathrm{~km}$ to reach the CEASA-Minas Grande BH (Fig. 4).

\section{Discussion}

The national general truck drivers' strike in Brazil reflected negatively on the availability and, consequently, the price of unprocessed foods. This scenario clearly reveals Brazil's dependence on roadways and the submission of urban areas to the conventional food market. It may also lend 
(a)

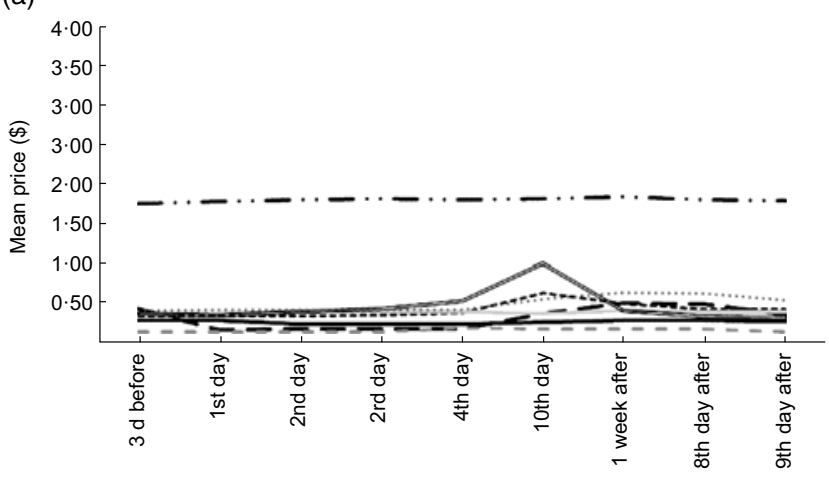

(c)

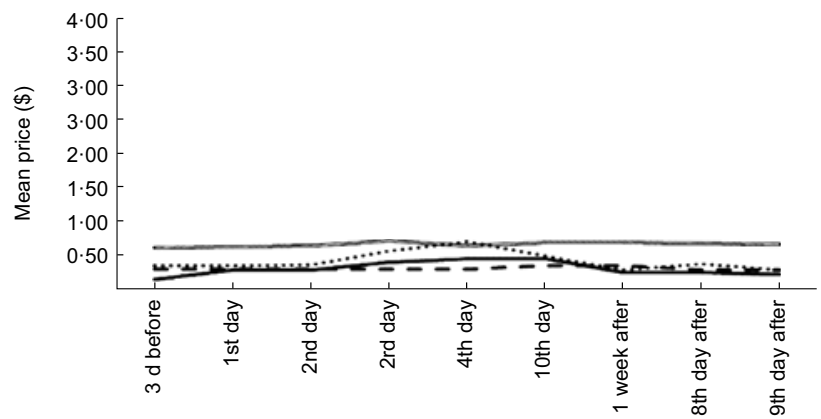

(b)

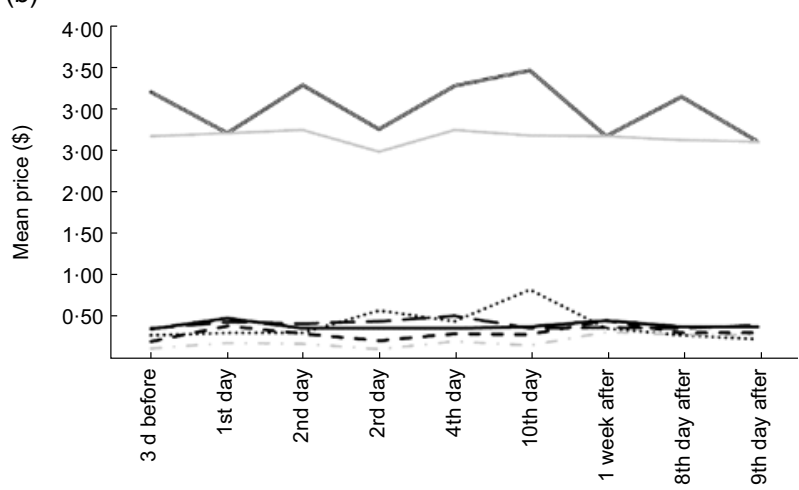

(d)

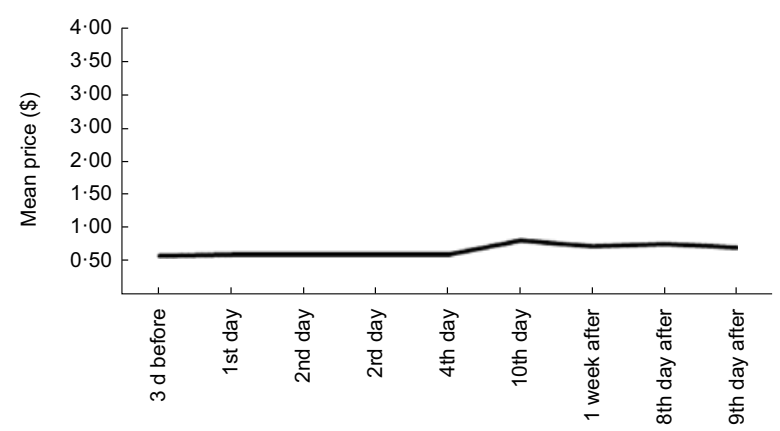

Fig. 3 Variation of the mean price, in US dollars (\$), of unprocessed foods per kilogram (unless noted otherwise) before, during and after the national general truck drivers' strike in Brazil, 2018, according to food group: (a) fruits (- - , banana; ----, orange; - - , apple; —, papaya; …....., mango; — , watermelon; ---, tangerine; -..-, grape); (b) vegetables (—, lettuce (dozen); - , kale (dozen); ;.......,

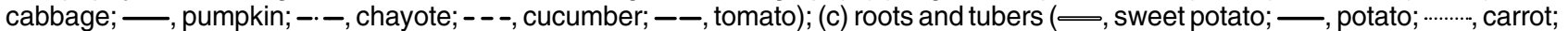
--- , cassava); and (d) eggs (dozen)

support to the idea that local and regional supply circuits can increase food security, especially during crisis situations, when the availability of food might affect economic access to food in terms of price.

In a short period of time, the fragility of the food supply cycle and the volatility of prices became notorious. This situation is even more serious when considering the spread of agricultural production, which requires long transport distances for foods to reach markets ${ }^{(9)}$. Although Brazil has a continental dimension, roads are the principal way to transport products in Brazil. Another aggravating point is that there is, to date, no systematic investment in other transportation methods; as a result, more than $60 \%$ of Brazil's products are transported by truck ${ }^{(17)}$, even though some regions' roads have less vascularity, increased density and poorer quality than the roads of other regions ${ }^{(18)}$.

Large percentage changes in food prices were observed during the strike, including for foods produced in the state (e.g. potatoes and carrots). This may result from the large territorial area of the state of Minas Gerais ${ }^{(10)}$. Thus, the complex supply network, in which products are transported exclusively by road, can be easily disrupted. This is the case even in a state in which one of the biggest highlights is the accessibility and density of its transport network. However, the observed percentage changes in food prices were not maintained for leafy vegetables (except for cabbage, which showed a significant price increase), possibly because they were produced predominantly in the surrounding areas of the CEASA-Minas Grande $\mathrm{BH}^{(19)}$. It is possible that the supply of this food may have been limited in a different way by the closure of the roads. Indeed, these additional questions should be investigated using qualitative research.

Although the state of Minas Gerais has an important role in unprocessed food production, the food supply centre buys products from other Brazilian states, too. In the context of national truck drivers' strikes, this is a risky alternative that tends to reduce the number of products available and raise prices. For instance, the main suppliers of fruits, which suffered big percentage changes in food prices during the strike (e.g. papaya and oranges), are located in the states of São Paulo and Bahia ${ }^{(10)}$. However, immediately after the truck drivers' strike ended, there was a rapid fall in the price of fruits. This may have been related to the storage of this product in cold rooms at the food supply centre to ensure the fruits' quality and contain the growth in prices. Additionally, during this period, due to a lack of fuel, a small number of retailers went to the CEASA-Minas Grande BH. Thus, after the strike, there was an oversupply of fruit, a normalization of demand and price reductions ${ }^{(20)}$. 
(a)

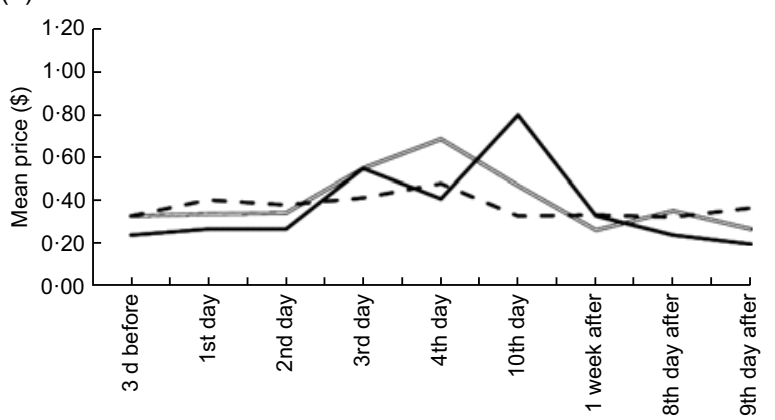

(c)

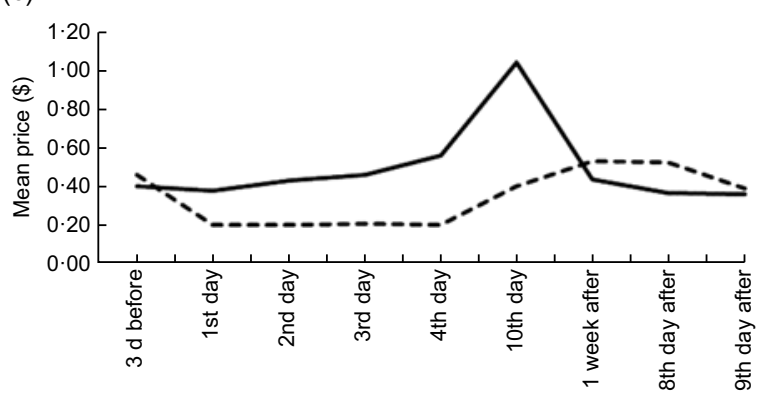

(b)

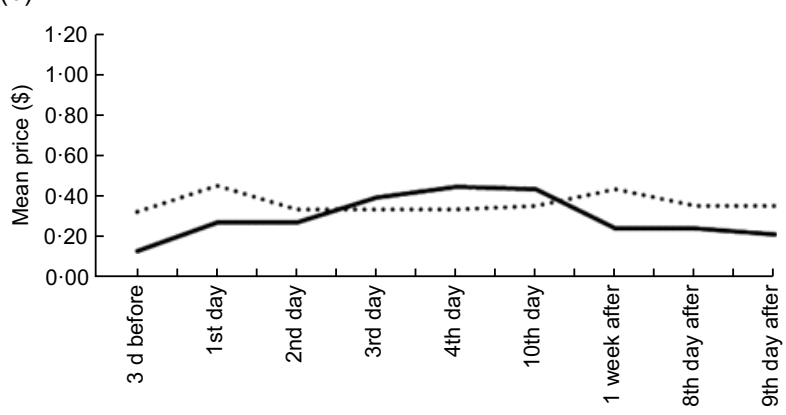

(d)

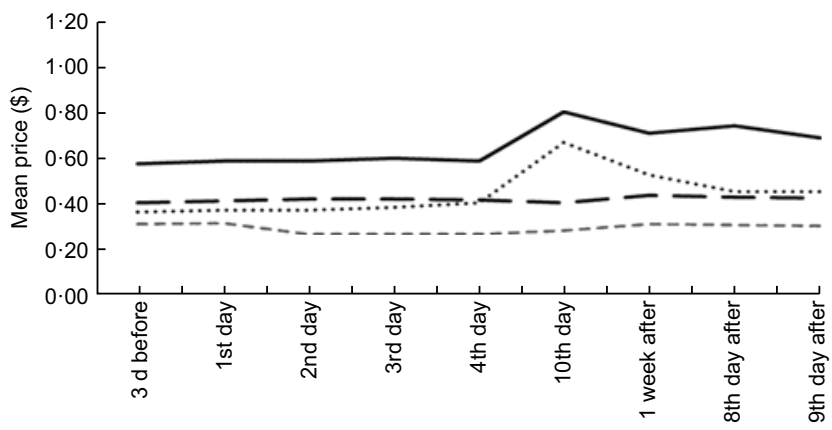

Fig. 4 Variation of the mean price, in US dollars (\$), of unprocessed foods per kilogram (unless noted otherwise) before, during and after the national general truck drivers' strike in Brazil, 2018, according to distance: (a) up to $250 \mathrm{~km}$ (- cabbage, mean of route $=203 \mathrm{~km} ;--$, tomato, mean of route $=142 \mathrm{~km} ; \Longrightarrow$, carrot, mean of route $=207 \mathrm{~km})$; (b) $251-500 \mathrm{~km}(\cdots \cdots$, pumpkin, mean of route $=380 \mathrm{~km} ;-$ - potato, mean of route $=410 \mathrm{~km}) ;$ (c) $501-750 \mathrm{~km}(---$, , banana, mean of route $=554 \mathrm{~km} ;$ - , papaya, mean of route $=731 \mathrm{~km})$; $(\mathrm{d})$ over $750 \mathrm{~km}(\cdots \ldots$. , orange, mean of route $=841 \mathrm{~km} ;--$, apple, mean of route $=1370 \mathrm{~km}$; --.-, watermelon, mean of route $=955 \mathrm{~km} ;$ - , eggs (dozen), mean of route $=902 \mathrm{~km}$ )

The strike also had important repercussions on the availability of chickens' eggs. The strike had little impact on the price of eggs, which was already reduced due to the large availability, which was due to a fall in exports ${ }^{(20,21)}$. Additionally, this product has a longer storage time $(60 \mathrm{~d})$ than the other items we investigated, which possibly allowed the centre to maintain a satisfactory supply of this food during the strike. However, the death of birds during the strike would possibly result in greater variation in the price of eggs. Although this is not the only plausible explanation for the price variation, this shows how catastrophic events can affect the supply of foods differently, which justifies more analyses of commercial dynamics in times of crisis.

Unlike the observations for eggs and fruits, the price variation of vegetables was greater after the strike (18 May and 6 June $v$. 18 May and 30 May) than before. Although what would happen after the strike was uncertain, we might expect prices to settle out. We speculated that to understand the message of the price variation of vegetables after the strike, we have to understand economic forces and the dynamics of the market. In the early days of May, before the strike, vegetable prices were already lower. Chayote, for instance, showed the highest increase after the strike; however, this price was $16 \%$ lower than it was in the previous month, revealing an important price change that would likely have occurred regardless of the strike situation $^{(20)}$.

The food supply chain size depends on the durability of the product ${ }^{(22)}$, where an industry is concentrated and/or where the product grows best. In addition, the impact of a national truck drivers' strike may depend on the distance that the food must travel to supply centres, the number of middlemen or 'stops' along the way, road size and quality, overtime of work (exceeding the contractual working hours or the company's normal working hours), stocks, climatic conditions, fluctuations in demand and supply, and the strategies used at food supply centres; in times of crisis, these factors can also impact the availability and price of foods and choice of alternative food suppliers ${ }^{(5,22,23)}$.

With regard to the impact of distance on prices, we identified that two of the three unprocessed foods with some of the greatest percentage changes in the food's price (potato and papaya) were produced more than $400 \mathrm{~km}$ away from the CEASA-Minas Grande $\mathrm{BH}$. This result suggests that there is a direct relationship between distance and price variation, but caution is needed in these interpretations.

The CEASA-Minas Grande BH works with products from other states to force disputes between markets, particularly in regard to prices ${ }^{(10)}$. However, when these foods are 
prevented from circulating, long-circuit production may also affect food prices. This question reveals not only the importance of reflecting on the general governance decisions of the public administration with respect to regulating the market and social commitments to food security for the population, but also on the regulation of work in road transport, which is perhaps the root cause.

The price decision process for a product involves evaluation of different complex variables. For instance, the price of a food may change with changes in the food's quantity and/or quality. As a result, the availability of food might affect economic access to food in terms of price. For example, if the prices of foods increase greatly, possibly families, especially low-income families, will decrease the quantity and/or quality of the foods they purchase. In this case, the price changes can generate food insecurity in the families' members $^{(1)}$.

Additionally, the number of stalled trucks, blocked road stretches ${ }^{(12)}$ and the reduction of offered foods by about $30 \%$, as revealed in the present study, showed the dimensions of solidarity with strikers. Although breaking a strike always presents an ethical dilemma, solidarity with strikers meant a threat to the public's food security. Therefore, if the strike had lasted longer, it may have had a significant negative impact on the food security of the Brazilian population.

The results of the present study reveal the dependency of the conventional market on truckers, but it should also be recognized that truck strikes can impair the country's ability to distribute locally/regionally produced food as well $^{(24)}$. Belo Horizonte is a national and international model for policies that link agricultural practices with sustainability. The city supports a considerable production of local and regional agriculture. Some would speculate that because such production uses shorter chains of production and consumption than does conventional agriculture, it may increase resilience to threats such as the truckers' strike ${ }^{(23-27)}$. We point out that regardless of food production and their chains, the quality of foods offered is also important, including attention to pesticide use.

However, if urban agriculture was expanded to a large enough scale to feed the city, it too would need truck transportation. The factor that creates resilience in this context is diversification. To achieve lasting resilience in a food system, diversity and redundancy are essential qualities. In other words, having diverse food supply chains that source foods from a mix of local, regional, national and global sources, and having more than one way for foods to enter the city, will make it more likely that a city's food supply is protected from a disruption in one food-producing region. That said, there are other benefits of local and regional agriculture for other dimensions of resilience, such as social use of the soil, preservation and proper use of water, minor use or no use of pesticides, besides stimulating the local economy, preservation and consumption of regional foods, among others.

Resilience varies from city to city, depending on the organizational capacity of each, and can minimize the apparent fragility of urban areas, since it deals with future uncertainty such as a crisis situation caused by a general strike $^{(23,28,29)}$.

Another critical way to promote resilience is to keep food system workers well-supported. In some alternative types of crisis, for example physically hazardous situations (pandemics and civil unrest), we would need truckers to take significant risks in order to get food to us. Good worker treatment may be one important part of their decision to do so. Also, good worker treatment could help prevent strikes, particularly since one of the main claims was associated with working conditions ${ }^{(13)}$. The importance of this resilience concept, however, is mostly addressed in terms of agricultural resilience in the literature; this limits our discussion and highlights the need for more studies ${ }^{(28)}$. Thus, our research points to the importance of exploring factors that contribute to food system resilience across the entire food supply chain ${ }^{(28)}$.

We believe that the present study is the first that evaluates the repercussions of a truck drivers' strike on the availability and price of foods. However, one limitation is that we analysed data for only wholesale foods and we did not investigate the consumer food environment. It is, however, considered inevitable that the reduction in the supply of foods and increase in prices practised by the main wholesale food retailer of the state reflect negatively on the consumer food environment. This is especially the case when we consider that its main buyers are establishments that specialize in fruits and vegetables for markets and supermarkets $^{(10)}$.

The year of reference (2004) of the index developed by the CEASA-Minas Grande BH (Índice de Quilometrização) to calculate the mean route distance, in kilometres, for the foods is also a limitation of the present study, as is the absence of these data for some items analysed. On the other hand, the index has an excellent CI and it is one of the most current references available from the institution $^{(16)}$.

Another study limitation was the inability to analyse other variables that could interfere with the availability and price of foods, such as climatic variations, food routes, normal market conditions and price fluctuations. Variations in food prices occur regularly, and so data on price fluctuations are essential for a more appropriate analysis of the impact of a national truck drivers' strike. Data on price fluctuations were not available and this issue limits the comparison to multiple time points. Additionally, qualitative data, from the staff, could help to explain: (i) what was actually happening; (ii) how the CEASA-Minas Grande $\mathrm{BH}$ prepared for the strike or how much advance warning suppliers had to prepare for the strike; and (iii) why prices 
changed. Nevertheless, when exploring secondary data from the food supply centre, the present study shows the relevance of investigating food availability and price in the wholesale network, especially during extreme crises, in order to minimize its effects.

\section{Conclusion}

To conclude, the national general truck drivers' strike in Brazil correlated with a reduction in the availability of unprocessed foods and, consequently, increases in prices and possibly restrictions on food access, which may affect food security. Moreover, the strike demonstrated the dependence of large urban metropolises on road transportation and access to the conventional market. We speculated that initiatives that aim to shorten the food supply chain, promote food sovereignty and promote the resilience of local and regional supply circuits can contribute to the human right to food and food security in crisis scenarios.

Additionally, the study showed that it is necessary to research the risks of food shortages in large metropolitan cities and better understand the food chain in these scenarios. We understand that a resilient food system should also treat food system workers well and that food sovereignty will not be achieved by simply replacing the way food is transported or solely with investments in other forms of transportation or the privatization of highways.

\section{Acknowledgements}

Acknowledgements: The authors thank the Centrais de Abastecimento de Minas Gerais S.A. and anonymous reviewers for their thorough reviews, constructive comments and suggestions. Financial support: This work was supported by Pro-Rectory of Research of the Universidade Federal de Minas Gerais (institution responsible for research) and was financed in part by the Coordenação de Aperfeiçoamento de Pessoal de Nível Superior, Brasil (CAPES; finance code 001) and the Conselho Nacional de Desenvolvimento Científico e Tecnológico (CNPq; research productivity scholarship to A.C.S.L.). The funders had no role in the design, analysis or writing of this article. Conflict of interest: None. Authorship: M.S.L.: conception and design; analysis and interpretation of data; drafting of manuscript; data collection and input; reviewed the final version of this manuscript and approved its publication. M.L.A.: drafting of manuscript; reviewed the final version of this manuscript and approved its publication. A.C.S.L.: conception and design; drafting of manuscript; critical revision of manuscript; technical and material support; reviewed the final version of this manuscript and approved its publication. Ethics of buman subject participation: Not applicable; this study is not human subjects research.

\section{Supplementary material}

To view supplementary material for this article, please visit https://doi.org/10.1017/S1368980019001939

\section{References}

1. Food and Agriculture Organization of the United Nations (2015) The State of Food Insecurity in the World. Meeting the 2015 international hunger targets: taking stock of uneven progress. http://www.fao.org/3/a-i4646e.pdf (accessed July 2019).

2. La Vía Campesina (1996) II International Conference of the Vía Campesina, Tlaxcala, Mexico, April 18-21. Tlaxcala Declaration of the Vía Campesina. https://viacampesina. org/en/ii-international-conference-of-the-via-campesinatlaxcala-mexico-april-18-21/ (accessed July 2019).

3. Araújo ML, Mendonça RD, Lopes Filho JD et al. (2018) Association between food insecurity and food intake. Nutrition 54, 54-59.

4. Costa NS, Santos MO, Carvalho CPO et al. (2017) Prevalence and factors associated with food insecurity in the context of the economic crisis in Brazil. Curr Dev Nutr 1, e000869.

5. Suweis S, Carr JA, Maritan A et al. (2015) Resilience and reactivity of global food security. Proc Natl Acad Sci U S A $\mathbf{1 1 2}$, 6902-6907.

6. Wegner RC \& Belik W (2012) Distribuição de hortifruti no Brasil: papel das Centrais de Abastecimento e dos supermercados. Cuad Desarro Rural 9, 195-220.

7. Centrais de Abastecimento de Minas Gerais S.A. (2018) Histórico. http://www.ceasaminas.com.br/historicogeral.asp (accessed June 2018).

8. Centrais de Abastecimento de Minas Gerais S.A. (2018) Ceasa em números. https://minas1.ceasa.mg.gov.br/ceasainternet/ _lib/file/docceasanumeros/Informacoesdasunidades2018. pdf (accessed June 2018).

9. Monteiro CA, Cannon G, Levy RB et al. (2016) NOVA. The star shines bright. Food classification. Public health. World Nutr 7, 28-38.

10. Andrade TRM \& Rosa EP (2014) Estudo de Procedência dos Principais Produtos. Estudos Técnicos das Centrais de Abastecimento de Minas - CeasaMinas, Contagem. http://www.ceasaminas.com.br/informacoesmercado/artigos/ procedencia_principais_produtos.pdf (accessed June 2018)

11. Cunha ARAA \& Campos JB (2006) A importância do CeasaMinas. AgroAnalysis 26, 23-25.

12. Recine E (2018) Por que uma crise de abastecimento em tão poucos dias? Le Monde Diplomatique Brasil, Brasília, 30 mai. https://diplomatique.org.br/por-que-uma-crise-deabastecimento-em-tao-poucos-dias/ (accessed December 2018).

13. Associação Brasileira dos Caminhoneiros (2018) Ofício ABCAM $n^{\circ} 34 / 2018$. As alíquotas incidentes no valor do óleo diesel. http://www.abcam.org.br/images/OFICIO-ABCAM--N-34---PRESIDENTE-MICHEL-TEMER-1.pdf (accessed July 2019).

14. Instituto Brasileiro de Geografia e Estatística (2010) Pesquisa de Orçamentos Familiares 2008-2009-POF. Rio de Janeiro, RJ: IBGE.

15. Centrais de Abastecimento de Minas Gerais S.A. (2018) Informações de Mercado. https://minas1.ceasa.mg.gov. br/detec/ofertas_prd_var/ofertas_prd_var.php (accessed December 2018). 
16. Rosa EP, Silva T \& Veiga Júnior WG (2005) Análise da Procedência dos Principais Produtos Hortigranjeiros Ofertados na Ceasaminas Grande BH - Indice de Quilometrização. Contagem, MG: Centrais de Abastecimento de Minas Gerais S.A.

17. Confederação Nacional do Transporte (2014) Plano CNT de Transporte e Logística. http://www.cnt.org.br/Paginas/ plano-cnt-transporte-logistica (accessed June 2018).

18. Instituto Brasileiro de Geografia e Estatística (2014) Logística dos Transportes no Brasil. ftp://geoftp.ibge.gov.br/redes_ e_fluxos_do_territorio/logistica_dos_transportes/mapa_Log Transportes_5mi.pdf (accessed June 2018).

19. Silva WF, Marques DJ, Silva EC et al. (2015) Diagnóstico da produção de hortaliças na região metropolitana de Belo Horizonte. Hortic Bras 33, 368-372.

20. Centrais de Abastecimento de Minas Gerais S.A. (2018) Hortigranjeiros ficam 2,5\% mais baratos em maio. http:// www.ceasaminas.com.br/noticiageral.asp?codigonoticia $=433$ 8 (accessed June 2018).

21. Associação Brasileira de Proteína Animal (2017). Relatório Anual 2017. http://abpa-br.com.br/storage/files/ 3678c_final_abpa_relatorio_anual_2016_portugues_web_ reduzido.pdf (accessed June 2018).

22. High Level Panel of Experts (2017) Nutrition and Food Systems. A Report by the High Level Panel of Experts on
Food Security and Nutrition of the Committee on World Food Security. Rome: HLPE.

23. Schimitt CJ (2011) Encurtando o caminho entre a produção e o consumo de alimentos. Agriculturas 8, 4-8.

24. Kubi A, Conard M, Culligan P et al. (2014) Sustainable food systems for future cities: the potential of urban agriculture. Econ Soc Rev 45, 189-206.

25. Ribeiro SM, Bógus CM \& Watanabe HAW (2015) Agroecological urban agriculture from the perspective of health promotion. Saude Soc 24, 730-743.

26. Almeida DAO, Marques LMFJ, Alencar VGSL et al. (2018) Um diálogo entre a agroecologia e a agricultura urbana em regiões metropolitanas. Rev Bras Agroecol 13, 168-180.

27. Rocha C (2016) Belo Horizonte: the opportunities and challenges of urban food security policy. In The Governance of City-Food Systems: Case Studies from Around the World, pp. 29-40 [M Deakin, N Borrelli and D Diamantini, editors]. Milan: Fondazione Giangiacomo Feltrinelli.

28. Tendall DM, Joerin J, Kopainsky B et al. (2015) Food system resilience: defining the concept. Glob Food Sec 6, 17-23.

29. Bailey R \& Wellesley L (2017) Chokepoints and Vulnerabilities in Global Food Trade. Chatham House Report. London: The Royal Institute of International Affairs. 